\author{
Lyashenko V., \\ Khomenko O., \\ Golik V., \\ Topolnij F., \\ Helevera 0.
}

\title{
SUBSTANTIATION OF ENVIRONMENTAL AND RESOURCE-SAVING TECHNOLOGIES FOR VOID FILLING UNDER UNDERGROUND ORE MINING
}

Об'єктом дослідження є технологія та технічні засоби для погашення порожнеч під час підземного видобутку руд в масивах, що енергетично порушені. Одним із найбільш проблемних місць є погашення техногенних порожнеч, які впливають на виникнення та перерозподіл напружено-деформаційного стану (НДС) масиву гірських порід. Їх існування в земній корі провокує порушення денної поверхні, а також вплив геомеханічних і сейсмічних явищ, аж до рівня землетрусів.

У роботі виконано аналітичні дослідження, порівняльний аналіз теоретичних і практичних результатів за стандартними та новими методиками за участю авторів. Розглянуті особливості прояву гірського тиску в скельних масивах складної будови, зумовлені інтенсивністю розривних структур (акустична жорсткість від 0,11 до 0,18 МПа/с, коефічієнт ударонебезпеки - 0,98). Досліджено умови прояву залишкової несучої здатності порушених порід і перекладу геоматеріалів у режим об'ємного стиснення (в зоні порушених порід коефіщієнт ослаблення знижується до 0,04-0,15 від початкової величини 0,25-0,35). Показана принципова оцінка стійкості виробок в неоднорідних скельних породах міцністю 50 - 150 МПа на глибинах до 600 м, що залежить від положення виробок щодо елементів структурної порушеності та можливості створення надійних конструкцій. Зроблено висновки про ефективність використання при погашенні виробленого простору несучих конструкцій із окремістей порід розмірами більше 0,2 м і механічною міщністю понад 50 МПа. Це дозволяє оголювати покрівлю без обвалення при прольотах оголень до 50 м. У разі рівного розподілу напружень в приконтурній зоні та мічності несучого шару порід вироблений простір може погашатися ізолячією або твердіючою закладкою мічністю до 1,2 МПа. Результати досліджень можуть бути використані при підземній розробці рудних родовищ складної структури України, Російської Федераціі, Республіки Казахстан та інших розвинених гірничодобувних краӥн світу.

Ключові слова: гірський масив, підземна розробка, погашення порожнеч, природоохоронна та ресурсозберігаюча технологія, ефективність горного виробництва.

\section{Introduction}

The efficiency indicators of underground mining of deposits of complex structure depend on the targeted use of the properties of ore-bearing massifs and technogenic conditions [1,2]. One of the main issues of exploitation of such deposits is the choice of parameters for the filling of voids formed by the extraction of raw materials, ensuring the safety of the earth's surface in the area of development [3, 4]. They lie in heterogeneous rock masses of complex structure, the behavior of which has its own characteristics that determine the economic, environmental and social consequences of technogenic interference in the natural environment $[5,6]$.

Therefore, the justification of environmental and resource-saving technologies for the filling of voids in underground ore mining is an important scientific, practical and social task that requires an operational solution [7, 8]. This is achieved by establishing patterns of manifestation of rock pressure in the rock mass to ensure the livelihoods of the population living in zones of influence of mining re- gions $[9,10]$. This work is a continuation of research, the main scientific and practical results of which are most fully described in [11].

\section{The object of research and its technological audit}

The object of research is the technology and technical means for the filling of voids in the underground mining of ores in energy-damaged massifs. One of the most problematic places is the filling of man-made voids that affect the occurrence and redistribution of the stress-strain state (SSS) of the rock mass. Their existence in the earth's crust provokes disturbance of the day surface, as well as the influence of geomechanical and seismic phenomena, up to the level of earthquakes.

\section{The aim and objectives of research}

The aim of research is the justification of environmental and resource-saving technologies for the filling of voids in 
underground ore mining. This will ensure the preservation of the daily surface and the vital activity of the population living in the zone of influence of the mining region.

To achieve this aim it is necessary to solve the following objectives:

1. To establish the features of the manifestation of rock pressure in rock masses of complex structure, due to the intensity of the explosive structures.

2. To determine the conditions for the manifestation of the residual bearing capacity of the disturbed rocks and the transfer of geomaterials to the volume compression mode.

3. To show what the stability of workings in heterogeneous rock with a strength of $50-150 \mathrm{MPa}$ at depths of up to $600 \mathrm{~m}$ depends on.

4. To evaluate the mining and geological conditions of rock deposits in energy-disturbed massifs, allowing to expose the roof of voids without collapse or to fill them by insulation or low-strength hardening laying.

\section{Research of exiting solutions of the problem}

Among the main directions of solving this problem identified in scientific resources, the following hypotheses can be distinguished. Thus, it has been proved by the practice of mining deposits localized in rock masses that the well-known theory described in [1] is more applicable for controlling their state. In accordance with this theory, only a mass of rocks enclosed within the arch, with a height significantly less than the depth of work, affects the development. In the future, this theory is concretized. In particular, the author of [2] established a decisive parameter - the tensile strength of the rocks that form the beam. And the author of the work [3] links it with the stability of the rock layer in the roof of the mine. The author of the work [4] defines the stable position of the mine as the equality between the strength of jammed rocks that form a hinged arch with an array within the arch of natural equilibrium. The stability of the massif is ensured under the condition of sufficient mechanical strength of the lower row of jammed structural blocks, loaded with an array of rocks within the arch of natural equilibrium. In the subsequent [5,6], scientists determine that the conservation of the earth's surface from destruction is ensured by the regulation of the stress level in different strength sections, the interdependence of ore excavation in time, space and its degree of preparedness for mining.

An analysis of the state and movement of technogenic voids shows that with an increase in the depth of development of ore deposits and the duration of the existence of chambers, the number of self-collapsing rocks in them increases. So, at the Frunze mine (Kryvbas, Ukraine) at the depth of $0-100 \mathrm{~m}, 1$ collapse occurred, and at a depth of 300-400 m there were already 25. At the Comintern mine (Kryvbas, Ukraine) had 8 collapses at a depth of $300-400 \mathrm{~m}$, and reached 35 at a depth of 600-700 $\mathrm{m}[7,8]$. Underestimation of these factors leads to the collapse of the surface in large areas, air strikes in underground workings and the social tension of residents living in the zone of influence of mining. This was confirmed during the collapse of the day surface on an area of 16 hectares of the Ordzhonikidze mine in Kryvbas (Ukraine) in 2010 [9, 10]. On this basis, new environmental and resource-saving tech- nologies and technical means for filling of voids were proposed, which gave positive results in underground mining of ore deposits in Ukraine, the Russian Federation, the Republic of Kazakhstan and other developed mining countries of the world [12,13].

Thus, the results of the analysis allow to conclude that the formation of technogenic voids, which affect the occurrence and SSS redistribution of the rock mass, is an important issue to solve. Their existence in the earth's crust provokes disturbance of the day surface, as well as the influence of geomechanical and seismic phenomena, up to the level of earthquakes [14, 15].

\section{Methods of research}

In the course of the study, methods of complex generalization, analysis and evaluation of practical experience and scientific achievements are used in the field of:

- technologies and technical means of filling of voids

during underground mining of ores in energy-distur-

bed massifs;

- underground geotechnology;

- theories and practices of explosive destruction of solid media.

On models of equivalent and optically active materials:

- influence of rock disturbance on the stability of the workings, the change in the magnitude and forms of manifestation of rock pressure with the depth of work is studied;

- dependences of the deformed-stressed state of the disturbed rocks on the dimensions of the workings are established.

Let's also use the methods of continuum mechanics, mathematical statistics, and methods of studying wave processes using standard and new methods of leading experts from developed mining countries of the world with the participation of the authors.

\section{Research results}

6.1. Study of the mechanism of stress and strain in the zone of influence of underground voids. In the practice of technology and technical means of filing of voids during underground ore mining in energy-damaged massifs, the following methods are most common (Fig. 1).

Filling by collapse of the enclosing rocks is the most common way, which is explained by the simplicity of the organization of work, a high degree of mechanization and low cost. Its disadvantages include difficulties in controlling the completeness of filling the voids and controlling the collapse process while reducing the capacity of ore bodies at depths of more than 500-600 m. When developing deposits at great depths, there is a need to switch to other technologies for filling of voids. The method is characterized by significant losses and dilution and destruction of the array to the surface. At the same time, when developing ore deposits under loose deposits, wet loams, getting into the mined ore, complicate, and sometimes disrupt the process of sorting waste rocks and substandard ores. They also impede the operation of mine transport, feeders, dispensers and skip hoisting. The noted shortcomings significantly reduce the effectiveness of the application of this method of filling of underground voids in the development of deposits of very valuable ores. 


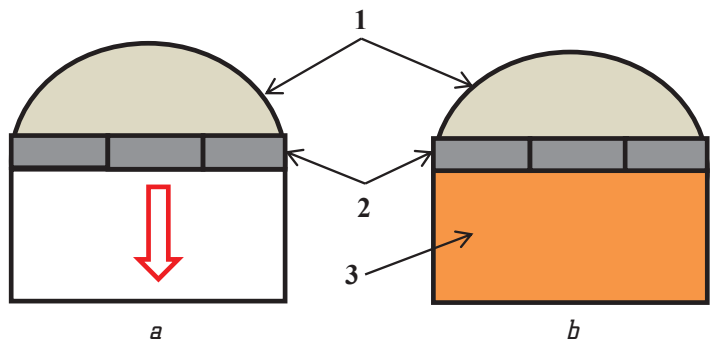

Fig. 1. The safety condition for rock caving: $a$ - open mined space; $b$ - worked out space laid down by the hardening mixture; 1 - collapse zone; 2 - bearing layer; 3 - hardening mixture

Filling by insulating voids with bridges without filling with material is used when mining ore bodies of low and medium power, flank and blind ore bodies that do not affect underground objects and the earth's surface. As the main one, this method is used in some fields of the Republic of Kyrgyzstan, the Republic of Kazakhstan, the USA, South Africa and other mining countries. The advantages of the method are minimal costs, relatively small losses and dilution, accessibility for control, the safety of the host array and the earth's surface. The technology features include an increased requirement for completeness of ideas about the massif, its more detailed knowledge and constant geomechanical and seismic monitoring [16, 17].

Filling by hardening filling mixture provides the best indicators of subsoil use (Fig. 2). The main volume of voids is laid with mixtures while simultaneously developing open and underground methods for powerful steeply falling ore bodies of deposits localized in intensively disturbed rocks of medium stability. Recently, a filling has been prepared with the replacement of cement with crushed binders mixed with sand and gravel materials. Filling strength varies widely, depending on the purpose of the artificial arrays. In a number of deposits, a hardening filling mixture is used because of the need to preserve the earth's surface according to environmental conditions and improve life safety in mining regions.

Technologies with filling voids with hardening mixtures occupy priority positions in underground mining of mineral deposits, in all conditions ensuring the safety of operating facilities, safe mining operations, completeness of use and protection of the subsoil, and the environment. The main tool for activating the ingredients of a hardening mixture is a disintegrator, which, when exposed to a substance, produces an impact speed an order of magnitude greater than in vibration and ball mills and an acceleration of millions of gravity accelerations [18, 19]. The activation of ores in the disintegrator is an element of combining technologies for leaching metals from substandard raw materials, increasing the extraction of metals and accelerating the processes of leaching of metals. Disintegration technology provides an increase in the activity of binders by up to $40 \%$ [20, 21].

The study of the parameters of a single process for processing ore dressing tailings - mechanical activation in a chemical leach disintegrator was carried out in the DESI-11 installation (Russia) manufactured by the Closed Joint-Stock Company Hephaestus Center for Applied Mechanochemistry, St. Petersburg, Russia (Fig. 3). Activation of the components of the mixture on a vibrating screen, in a disintegrator and a vibrating pipeline with activation of water by precipitation of salts and impurities expands the use of advanced technologies with hardening mixtures $[22,23]$.

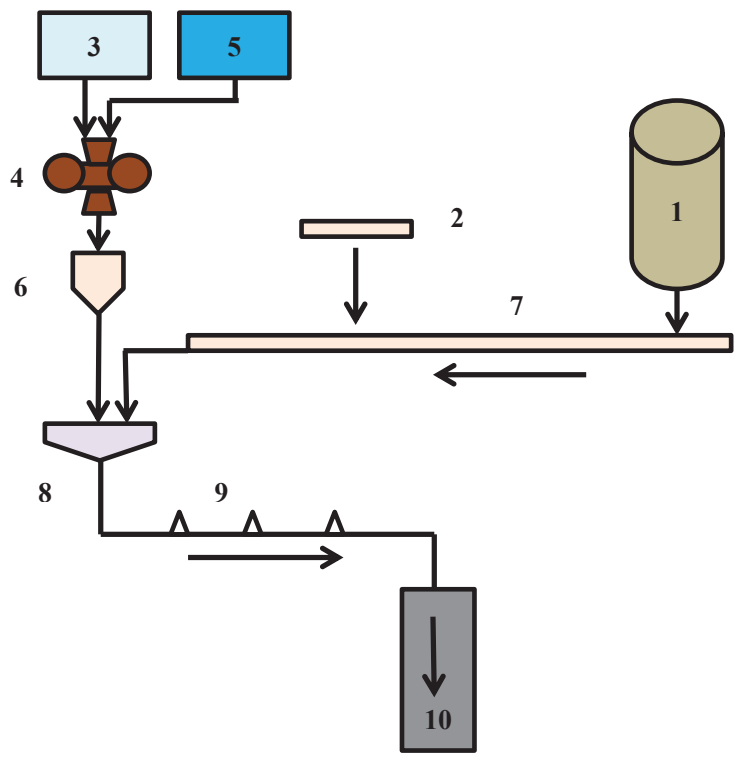

Fig. 2. Scheme of activation of components of hardening mixtures during their manufacture and transportation: 1 - cement hopper; 2 - vibrating screen of inert aggregates;

3 - blast furnace slag; 4 - disintegrator-activator DU-65 ("Disintegrator» company, Estonia); 5 - activated mixing water; 6 - vertical vibratory mill MVV-0.7 (Ukraine); 7 - conveyor; 8 - mixer; 9 - vibrators; 10 - block camera

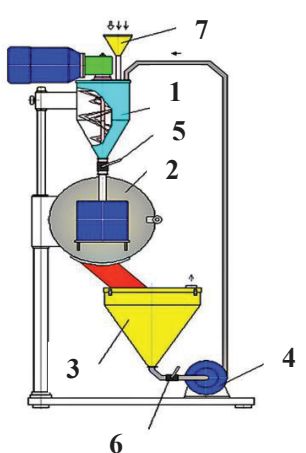

Fig. 3. Scheme of laboratory disintegrator DESI-11 for activation and leaching of minerals: 1 - mixer; 2 - disintegrator; 3 - receiving hopper; 4 - pump; 5, 6 - crane; 7 - funnel

Combined void filling in the development of ore deposits by underground block leaching (UBL) is used in developed mining countries of the world (Fig. 4). During two-stage ore mining, the reference pressure is redistributed to the chambers of the second stage, and the load on the structures is determined by the mass of rocks inside the arched arch of natural rock equilibrium. Damaged rocks within the arch are deformed, but can form a solid structure and not interfere with the leaching process [24, 25]. Geotechnologies are promising, in which rich ores are emitted on the day surface, and the rest of the ore is processed at the place of occurrence. Geochemical technologies for the leaching of metals provide for the supply of a leaching solution (in this case, low-concentrated solutions of sulfuric acid, that is, ersatz acid) to the ore-containing material. As well as the preparation of the receiving horizon in the form of a bottom, prepared and silted with clay solution at an angle of $5-6^{\circ}$ in the direction of collecting the productive solution. Metal leaching time is up to 6 months. After that, the productive solution is collected in containers and sent for subsequent and more complete processing at the 
hydrometallurgical plant (GMP). And the leached material is left in spent chambers as filling material with a strength of up to $1.2 \mathrm{MPa}$ and washed with water through the existing irrigation system to reduce harmful substances entering the geological environment (Table 1).

Fig. 4. Combined development of the ore deposit: 1,2 - respectively, rich and poor in the content of the useful ore component; 3 - complex heap leaching of poor and off-balance ores; 4, 5 - respectively, the ore control and concentration station (OCS) and the factory (OCF); 6 - filling complex; 7 - workshop for the preparation of leach solutions

Typification of processes of underground block leaching of ores

\begin{tabular}{|c|c|c|}
\hline Processes & Process parameters & Process conditions \\
\hline Оге crushing & Coarse particle size $+20-50 \mathrm{~mm}$ & $\begin{array}{l}\text { Uniform ore density. } \\
\text { The possibility of creating } \\
\text { a compensation space for } \\
\text { the explosion }\end{array}$ \\
\hline Оre irrigation & $\begin{array}{l}\text { Wells in an untouched massif. } \\
\text { Spraying from the surface of the ore. } \\
\text { Wells in destroyed ore with casing. } \\
\text { The use of fine-grained materials. } \\
\text { Hydraulic fracturing }\end{array}$ & $\begin{array}{l}\text { Lack of impervious zones } \\
\text { and channels in broken } \\
\text { ore }\end{array}$ \\
\hline $\begin{array}{l}\text { Collection } \\
\text { of production } \\
\text { solutions }\end{array}$ & $\begin{array}{l}\text { Impervious curtains. } \\
\text { Waterproofing of leaching sites. } \\
\text { Electrovacuum drainage of solutions. } \\
\text { The use of synthetic polymeric materials }\end{array}$ & $\begin{array}{l}\text { Prevention of leaching } \\
\text { products into the envi- } \\
\text { ronment }\end{array}$ \\
\hline $\begin{array}{l}\text { Process } \\
\text { intensification }\end{array}$ & $\begin{array}{l}\text { Physical methods: injection of compressed air, } \\
\text { ore blasting, particle size reduction in propor- } \\
\text { tion to the concentration gradient, breaking with } \\
\text { layers with a variable line of least resistance, } \\
\text { shaping the ellipsoid of the outlet, ultrasonic vi- } \\
\text { brations, electromagnetic treatment of solutions. } \\
\text { Chemical methods: washing with water with } \\
\text { activating additives, the introduction of chemi- } \\
\text { cal compounds. } \\
\text { Biological methods: the use of strains of bacteria }\end{array}$ & $\begin{array}{l}\text { Obtaining the specified } \\
\text { loosening. } \\
\text { Increase in the content in } \\
\text { the solution to an accept- } \\
\text { able value }\end{array}$ \\
\hline $\begin{array}{l}\text { Leach } \\
\text { completeness } \\
\text { control }\end{array}$ & $\begin{array}{l}\text { Downhole methods: rock drilling for the in- } \\
\text { troduction of contral devices, drilling through } \\
\text { broken ore with sampling. } \\
\text { Saving workings with sampling }\end{array}$ & $\begin{array}{l}\text { Representative samples } \\
\text { and measurements for } \\
\text { the entire block }\end{array}$ \\
\hline
\end{tabular}

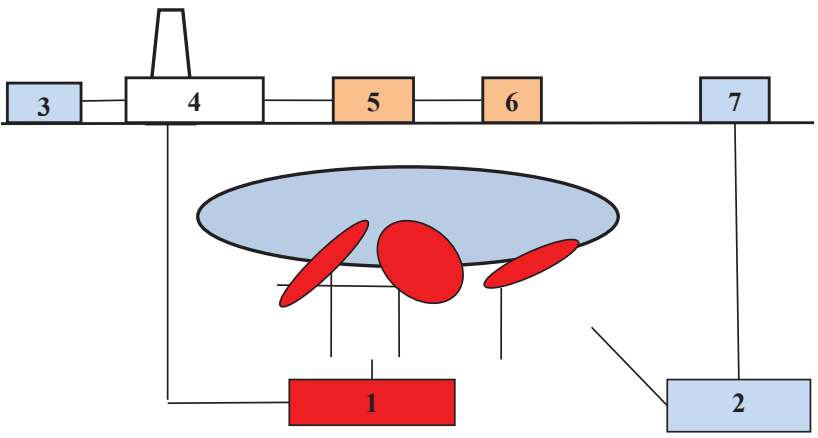

technogenic system [26, 27]. The balanced state of the ore-bearing array is ensured if the UBL blocks are unloaded from critical stresses by artificial and natural arrays. Within the production block, rich ore in the amount of about $40 \%$ of the reserves is extracted and released to the earth's surface, and the rest is leached in the UBL block. The issues of maintaining arrays are answered by leaching without destroying the array due to injection of reagents under high pressure in the UBL upper part and the collection of productive solutions in the workings of the bottom of the block.

6.2. The practice of preparing ore reserves for UBL. For ore deposits of the Michurynskyi deposit (Kropyvnytskyi, Ukraine), the angle of incidence between the axes $78-80$ varies from $57^{\circ}$ to $60^{\circ}$. According to the uprising, it is located between the horizons 255 and $202 \mathrm{~m}$. Preparation and cutting of the ore deposit is carried out for one or more operational blocks. Under-floor drilling and approach workings are carried out along the ore body and in the lying side of the deposit, rebelling, respectively, ventilation and overflow, bypass for the ore mass and cargo, cutting uprising for the formation of a cutting gap (compensation space) and development of

Table 1 the bottom of the block for collecting productive solutions. On the horizon $210 \mathrm{~m}$, a sorption column, a container for receiving the sorbent, a main pipeline and sprinklers for supplying a leaching solution to the stained ore in the UBL chamber are mounted.

Combined control of the geomechanics of energy-disturbed massifs is used in the extraction of different-grade ores, for example, after the extraction of rich ores, and poor ores are being finalized in UBL blocks [28, 29]. The geomechanical balance of the massif is ensured by dividing it into the limiting sections of the arch of natural equilibrium and maintaining a flat roof (Fig. 5). Inside the isolated areas, various underground ore mining technologies can be applied. The protection of the conjugate sections of the field from the seismic effects of explosives is, for example, shielding.

The stress level in the geomechanical system is regulated by engineering measures:

- inclination of the artificial massif on the ore mass reduces the dilution of ore filling; - protective filling array at the border of the ore deposit is a protective wall, allowing to extract the main reserves in favorable mining conditions;

- hardening of unstable rocks with anchors and steel ropes provides better ore recovery rates.

Development of UBL ore deposits involves the creation of areas with rocks of different strength in energydisturbed massifs:

- blocks are filled with ore material, which is mobile and prone to caking;

- blocks are characterized by water saturation and weakening of rock strength;

- mineral particles move in the process of leaching.

The creation of such sections provokes an increase in tensile stresses and loads on the elements of the natural-
Thus, the analysis of retro- and prospects for the development of methods of filling of voids in the development of deposits shows:

- development of environmental and resource-saving trends limits, up to a complete ban, the scope of the method of filling with caving;

- spread of the filling method by isolation is limited by the main one this method can be applied in exceptional cases. As an auxiliary method, its scope is increasing; the conditions for the localization of ore bodies, and as 
- limiting factor for increasing the scope of hardening filling mixtures is the shortage of binders and highquality aggregates, which reinforces the need to involve production waste and local substandard mineral resources such as loam and sandy loam in the production sphere; - choice of filling parameters requires a deeper knowledge of the patterns of managing arrays with combined filling: hardening backfill mixtures and isolation, as well as technical and technological support of filling processes using nature and resource-saving technologies [30, 31].

earthquake-safe mass of charges and their impact on the safe conduct of mining operations in the depth range of 300-1000 m when mining ore deposits with chamber development systems with the laying of the mined-out space at Ukrainian mines. The dependences of safe and stable parameters of treatment units on mining and geological and mining conditions, physical and mechanical properties of rocks and artificial massifs, and exposure time of outcrops of worked out spaces are given. The conditions of safe mining operations, the procedure for determining the size of hazardous areas and the brittle destruction of rocks subject to SSS are described. Criteria are formulated to assess the intensity and mechanisms of manifestation of rock pressure depending on the level of SSS and the deformation characteristics of the rocks [32, 33].

The experimental development of new technologies for the activation of components of hardening mixtures during underground ore mining was carried out at Tselinnyi Mining and Chemical Combine JSC (Stepnogorsk, the Republic of Kazakhstan). The results allow to conclude that the combination of methods for activating the ingredients of the mixture has several advantages, the main of which are the possibility of increasing the raw material base, increasing the coefficient of completeness of the resources of the subsoil, and the possibility of delivering the mixture to a distance significantly exceeding the limit for traditional technologies. This allows to fill the construction of new filling complexes. The effectiveness of the preparation and transportation of hardening mixtures over long distances is determined by the interaction of not only known factors, but also by the imposition of an activation factor on them. condition of the formation of the arch of natural equilibrium; $H$ - depth of work; $h_{c}$ - heigh of the arch of the natural equilibrium of the limiting span; $h_{1}-$ height of the new arch

6.3. Implementation results. The following instructions for the State Enterprise «Eastern Mining and Processing Plant» (SE «VostGOK», Zhovti Vody, Ukraine):

- «Instruction on the justification of safe and stable parameters of treatment units at the mines of the $\mathrm{SE} \ll$ VostGOK»

- «Instruction on the justification of safe mining operations and the procedure for mining ore deposits at the mines of $\mathrm{SE} \ll \operatorname{VostGOK}$;

- «Instructions for the operational monitoring and forecasting of the stress-strain state of rock and ore masses at the mines of SE «VostGOK» ware compiled based on the results of many years of research carried out in 1970-2019 by organizations such as:

a) State Enterprise «Ukrainian Research and Design Institute of Industrial Technology» (SE «UkrNIPIIpromtekhnologii», Zhovti Vody, Ukraine) and State Enterprise «Research Mining Institute» (Kryvyi Rih, Ukraine);

b) Joint-stock company All-Russian Scientific Research Institute of Mining Geomechanics and Mine Surveying (St. Petersburg, Russia), as well as taking into account best practices in developed mining countries of the world.

The instructions set out the calculation methods and presented nomograms for determining safe and stable outcrops of mountain and man-made arrays of treatment units, the permissible volumes of man-made voids of spent, partially filled and isolated worked out spaces. As well as the
When using the new technology, the completeness of the use of subsurface resources is increased, land for agricultural production is saved, and the environmental burden is reduced by eliminating the danger of storing chemically hazardous tailings for metal ore dressing.

Thus, the use of vibration, mechanical and electroactivation of the components of the hardening filling mixture in mining enterprises leads to an increase in the activity of substandard materials by up to $10-40 \%$ for each device. In particular, the enrichment of inert materials at the GV-1.2/3.2 vibrating screen (Ukraine) increases the activity by $15-20 \%$. Activation of binders (blast furnace granulated slag) in the DU-65 disintegrator - by $20-25 \%$, with the output of the active class of fractions with a particle size of $0.074 \mathrm{~mm}$ - by $55 \%$ versus $40 \%$ in ball mills. For a vertical vibratory mill MVV-0.7 - by $15-20 \%$, with the output of an active class of fractions with a particle size of $0.074 \mathrm{~mm}$ - up to $70 \%$. Vibration transport systems increase activity by $10-15 \%$, and electrodialysis devices for activating mixing water increase activity by $30-40 \%$. The use of vibro-gravity transport installations ensures the filling of the filling mixture at a distance of 15-20 times the height of the vertical stand [34, 35].

6.4. Environmental and economic efficiency of mining. The main criterion for the effectiveness of filling is the filling cost per $1 \mathrm{~m}^{3}$ of repaid voids. The least cost is 
the filling method with the collapse of the rocks and the destruction of the earth's surface, which was adopted during the development of most deposits of Kryvbas (Kryvyi Rih, Ukraine). This approach is not objective, because the collapse is inextricably linked with the destruction of the massif, the earth's surface and the loss of part of the raw materials. It is not possible to calculate the damage from this. The actual value of 1 ha of land diverted from agriculture does not correspond to the value paid to the land owner as compensation. The cost of one unit of lost metal is unstable and may increase many times in the near future. This is especially true for uranium feed and rare earths. Therefore, when comparing the cost of filling without taking into account actual damage, systematic errors are made. As a criterion for choosing the optimal method of filling, the authors take the minimum reduced filling cost provided that the earth's surface is preserved above the developed array, taking into account the caused (or preventable) damage to the environment and the costs of protecting the population living in the zone of influence of mining enterprises (mining and processing), according to Golik-Lyashenko analytical model [36, 37]:

$$
\left\{\begin{array}{l}
L_{a} \leq L_{f}=1.71 \cdot \sqrt[3]{\frac{10 R_{c m} d_{f 2}^{2}}{K_{2} \gamma}} \leq L_{b} ; \\
L_{a} \leq L_{l}=1.49 \cdot d_{b 2} \sqrt{\frac{10 R_{c m} d_{f 2}^{2}}{K_{2} \cdot \gamma \cdot b}} \leq L_{b} ; \\
L_{a} \leq L_{f x}=2.98 \cdot d_{b 2} \cdot \sqrt{\frac{10 R_{c m} d_{f 2}^{2}}{K_{2} \gamma}} \leq L_{b} ; \\
H>h_{c}=\frac{L_{b} \cdot d_{1}}{2 \cdot d_{2}} ; \\
K_{2}=\frac{20 R_{c m} \cdot d_{1}}{\left(L_{b}+2 d_{1}\right) H}>1 ; \\
P_{i}=\sum_{i=1}^{n}\left(V_{p r}-C_{p r} \pm Y+P_{p}\right) \cdot \frac{1}{1+E^{t-1}} \cong \max ,
\end{array}\right.
$$

where $L_{a}, L_{f}, L_{l}, L_{f x}, L_{b}$ - respectively, the actual, loose, fixed and boundary (limit) spans of the main and immediate roofs, $\mathrm{m} ; R_{c m}$ - temporary resistance of rocks to uniaxial compression, $\mathrm{kg} / \mathrm{cm}^{2} ; d_{f 2}, d_{b 2}$ - vertical size of structural blocks of the main and immediate roofs, $\mathrm{m} ; K_{2}-$ safety factor, units; g - rock density, $\mathrm{t} / \mathrm{m}^{3} ; d_{1}, d_{2}-$ size of the structural blocks, respectively, horizontally and vertically, $\mathrm{m}$; $b$ - power of the direct roof, m; $H$ - depth of work, m; $h_{c}$ - height of the zone of rock weakening, m; $P_{i}-$ profit from the development of ore reserves; $V_{p r}$ - the total value of the final product from metal-containing ores, monetary units; $C_{p r}$ - the total cost of production and receipt of the final product, cash; $B$ - the total damage caused to (-) the environment or preventing $(+)$, taking into account the costs of protecting the population living in the zone of influence of mining enterprises $\left(P_{p}\right)$, monetary units; $E$ - coefficient of discounting costs and profits over time $t$ using the evaluated technology, the share of units.

Thus, an analysis of the consequences of applying this criterion shows that the filling of voids with the collapse of rocks is excluded and the prerequisites for the development of array management methods are created. This condition is acceptable for most ore deposits of polymetallic, nonferrous, rare earth, radioactive metals located in areas of developed agriculture and under protected facilities. An assessment of the scientific basis and practice of filling of voids in the development of ore deposits of the Russian Federation, the Republic of Kazakhstan, Ukraine and other developed mining countries shows that:

- condition for the effective management of mountain ranges during their underworking is a geomechanical balance of stress - strain discrete media;

- promising methods of managing arrays are associated with the use of the residual bearing capacity of structural units composing them when transferring to volume compression mode.

\section{SWOT analysis of research results}

Strengths. Based on the study of the mechanism of occurrence and redistribution of SSS of rock mass using geophysical and surveying methods, a nature-conservation technology for the filling of voids in energy-disturbed massifs is proposed. It allows to ensure the safety of the day surface and the vital activity of the population living in the zone of influence of mountain objects. These include mines, waste dumps and off-balance ones, in terms of useful component content, ores, industrial sites for filling complexes, preconcentration and heap leaching of metals from substandard ore raw materials, tailings, etc.

Weaknesses. The main negative impact of mining technology on the environment and humans is the high cost of preserving the daily surface and ensuring the livelihoods of the population living in the zone of influence of mountain objects, the removal of large areas of land from use, etc. Therefore, it is necessary to provide funds for the following activities:

- deep processing of industrial waste (tailings), which have a wide variety of mineral forms compared to conventional ores;

- reclamation of the territory of industrial sites and the territory adjacent to them after the end of operation;

- landscaping of the reclaimed territory with grass and shrubs;

- continuous monitoring of environmental components in the zone of influence of mountain objects.

Opportunities. For the processing of industrial waste (tailings), it is necessary to create new technologies based on the latest achievements of science and technology. It is necessary to conduct intensive research aimed at solving the problem of disposal of accumulated waste from mining and metallurgical production (MMP). Implementation of effective methods for the extraction of metals from such wastes will improve the environmental situation in the areas of their storage and will provide an increase in the mineral resource base of the mining industry. The wide involvement in the production of technogenic reserves of ore dressing tailings, as well as the processing of off-balance dumps, in terms of the content of useful components, of ores in modular plants, contribute to obtaining an additional source for industry in metals. As well as reducing environmental pollution in developed mining countries of the world [38, 39].

Threats. It should be noted separately the need to create protective forest belts along transport routes (automobile, railway, slurry pipelines, etc.). Territories where the maximum permissible concentration (MPC) of pollutants is exceeded should be transferred to the sowing of industrial crops, in the waters - ban fishing, bathing, etc. In order to prevent the dust transfer of contaminated material outside mountain objects, sanitary protection zones and strips around it is 
advisable to plant them with tall tree species that will inhibit wind speed over these objects. These include mines, waste rock dumps and off-balance ones, according to the content of the useful component, ores, filling complexes, sites of preconcentration and heap leaching of metals from substandard ore raw materials, tailings, etc. In this case, dust will settle in these forest stands and will not come to other territories, including settlements. In addition, it is necessary to develop scientific and methodological foundations, technologies and technical means to increase the fertility and efficiency of soil use in industrial zones of mountain objects, as well as to assess their impact on the environment and humans [11, 40].

\section{Conclusions}

1. The features of the manifestation of rock pressure in rock masses of complex structure, due to the intensity of discontinuous structures, are established. It is shown that the acoustic rigidity is from 0.11 to $0.18 \mathrm{MPa} / \mathrm{s}$, the shock hazard coefficient is 0.98 .

2. The conditions for the manifestation of the residual bearing capacity of the disturbed rocks and the transfer of geomaterials to the volume compression mode are determined. Thus, in the zone of disturbed rocks, the attenuation coefficient decreases to $0.04-0.15$ from the initial value of $0.25-0.35$. The horizontal stresses in the massifs are 5 times higher than the vertical ones, which confirm the intense tectonics of the deposits.

3. It is shown that the stability of workings in heterogeneous rock with a strength of 50-150 MPa at depths of up to $600 \mathrm{~m}$ depends on the position of the workings relative to structural disturbance elements and the possibility of creating reliable structures.

4. It has been proved that the use of supporting structures of separate rocks with dimensions of more than $0.2 \mathrm{~m}$ and mechanical strength of more than $50 \mathrm{MPa}$ when redeeming the worked out space allows the roof to be exposed without collapse during exposure spans of up to $50 \mathrm{~m}$. With equal stresses in the marginal zone and rock bearing layer the developed space can be filled by insulation or a hardening tab with a strength of up to $1.2 \mathrm{MPa}$

\section{Acknowledgement}

Specialists participated in the organization of creation, improvement and implementation of scientific developments:

- SE «UkrNIPIIpromtekhnologii» and SE «VostGOK» (Zhovti Vody, Ukraine);

- National Technical University «Dnipro Polytechnic» and the Institute of Geotechnical Mechanics named by N. S. Poliakov of the National Academy of Sciences of Ukraine, Dnipro, Ukraine;

- State Higher Educational Institution «Kryvyi Rih National University», Kryvyi Rih, Ukraine.

- JSC «VNIPIpromtekhnologii» and JSC «VNIMI», St. Petersburg, Russia;

- JSC «Tselinnyi Mining and Chemical Combine» (Stepnogorsk, Republic of Kazakhstan).

\section{References}

1. Protodiakonov, M. M. (1933). Davlenie gornykh porod i rudnichnoe kreplenie. Ch. 1. Davlenie gornykh porod. Moscow, Leningrad: Novosibirsk: Gosgortekhizdat, Ch. 1, 128.
2. Slesarev, V. D. (1948). Opredelenie optimalnykh razmerov tselikov razlichnogo naznacheniia. Moscow, Leningrad: Ugletekhizdat Zapaduglia, 195.

3. Borysov, A. A. (1948). Davlenye na krep horyzontalnykh vyrabotok. Moscow; Lenynhrad: Uhletekhyzdat, 104.

4. Vetrov, S. V. (1975). Dopustimye razmery obnazhenii gornykh porod pri podzemnoi razrabotke rud. Moscow: Nauka, 223.

5. Borisov, A. A. (1980). Mekhanika gornykh porod. Moscow: Nedra, 359 .

6. Fisenko, G. L. (1980). Predelnoe sostoianie gornykh porod vokrug vyrabotok. Moscow: Nedra, 359.

7. Sleptsov, M. N., Azymov, R. Sh., Mosynets, V. N. (1986). Podzemnaia razrabotka mestorozhdenyi tsvetnykh y redkykh metallov. Moscow: Nedra, 206.

8. Avdeev, O. K., Pukhalskii, V. N., Razumov, A. N. (1989). Otrabotka zapasov rudy $\mathrm{v}$ zone predokhranitelnogo tselika pod vodoemom. Gornyi zhurnal, 9, 28-30.

9. Instruktsiia po bezopasnomu vedeniiu gornykh rabot na rudnykh i nerudnykh mestorozhdeniiakh (obektakh stroitelstva podzemnykh sooruzhenii), sklonnykh $k$ gornym udaram (1989). Leningrad: VNIMI, 58.

10. Povnyi, B. E., Golik, V. I., Liashenko, V. I. (1991). Upravlenie pogasheniem tekhnogennykh pustot. Izv. vuzov. Gornyi zhurnal, 8, 24-30.

11. Lyashenko, V., Khomenko, O., Topolnij, F., Golik, V. (2020) Development of natural underground ore mining technologies in energy distributed massifs. Technology Audit and Production Reserves, 1 (3 (51)), 17-24. doi: http://dx.doi.org/10.15587/23128372.2020 .195946

12. Shtele, V. I. (1991). Stend dlia modelirovaniia geomekhanicheskikh protsessov $v$ tolsche gornykh porod. Avtorskoe svidetelstvo 1682559 A1 (SSSR).

13. Liashenko, V. I., Golik, V. I., Razumov, A. N., Trapenok, N. M. (1992). Prirodo- $i$ resursosberegaiuschie tekhnologii podzemnoi razrabotki rudnykh mestorozhdenii. Moscow: Chermetinformatsiia, 103.

14. Liashenko, V. I., Golik, V. I., Kolokolov, O. V. (1994). Sozdanie i vnedrenie prirodo- i resursosberegaiuschikh tekhnologii podzemnoi razrabotki mestorozhdenii slozhnoi struktury. Izv. vuzov. Gornyi zhurnal, 4, 31-37.

15. Chernova, A. P. (Ed.) (2001). Dobycha i pererabotka uranovykh rud. Kyiv: Adef-Ukraina, 238.

16. Liashenko, V. I. (2015). Nauchno-tekhnicheskie predposylki povysheniia ekologicheskoi bezopasnosti v gornodobyvaiuschem regione. Biul. Chernaia metallurgiia, 1, 21-30.

17. Liashenko, V. I., Pukhalskii, V. N. (2015). Justification of chamber safety parameters in underground working of surface reserves of deposits under protected sites. Izv. vuzov. Gornyi zhurnal, 3 , 37-49.

18. Komaschenko, V. I., Vasilev, P. V., Maslennikov, S. A. (2016) Dependable raw materials base for underground mining the KMA deposits. Izvestiia Tulskogo gosudarstvennogo universiteta. Nauki o Zemle, 2, 101-114.

19. Dmitrak, Y. V., Kamnev, E. N. (2015). The Leading Research and Design Institute of Industrial Technologies - A long way in 65 years. Gornyi Zhurnal, 3, 6-12. doi: http://doi.org/10.17580/ gzh.2016.03.01

20. Golik, V., Komashchenko, V., Morkun, V., Zaalishvili, V. (2015) Enhancement of lost ore production efficiency by usage of canopies. Metallurgical and Mining Industry, 7 (4), 325-329.

21. Golik, V. I., Rasorenov, Y. I., Efremenkov, A. B. (2014). Recycling of Metal Ore Mill Tailings. Applied Mechanics and Materials, 682, 363-368. doi: http://doi.org/10.4028/www. scientific.net/amm.682.363

22. JianPing, Y., WeiZhong, C., DianSen, Y., JingQiang, Y. (2015) Numerical determination of strength and deformability of fractured rock mass by FEM modeling. Computers and Geotechnics, 64, 20-31. doi: http://doi.org/10.1016/j.compgeo.2014.10.011

23. Dold, B., Weibel, L. (2013). Biogeometallurgical pre-mining characterization of ore deposits: an approach to increase sustainability in the mining process. Environmental Science and Pollution Research, 20 (11), 7777-7786. doi: http://doi.org/10.1007/ s11356-013-1681-2

24. Eremenko, V. A., Lushnikov, V. N. (2018). Procedure for selecting dynamic ground support for rockbursting mining conditions. Mining Informational and Analytical Bulletin, 12, 5-12. doi: http://doi.org/10.25018/0236-1493-2018-12-0-5-12 
25. Reiter, K., Heidbach, O. (2014). 3-D geomechanical-numerical model of the contemporary crustal stress state in the Alberta Basin (Canada). Solid Earth, 5 (2), 1123-1149. doi: http:// doi.org/10.5194/se-5-1123-2014

26. Goodarzi, A., Oraee-Mirzamani, N. (2011). Assessment of the Dynamic Loads Effect on Underground Mines Supports. 30th International Conference on Ground Control in Mining, 74-79.

27. Sokolov, I. V., Antipin, Iu. G., Baranovskii, K. V. (2017). Construction and parameters of the combined system for developing quartz slope deposit. Bulletin of the Tomsk Polytechnic University. Geo Assets Engineering, 328 (10), 85-94.

28. Smirnov, S. M., Tatarnikov, B. B., Aleksandrov, A. N. (2014) Influence of the current geodynamic mining situation on stopingand-backfilling operations. Gornyi informatsionno-analiticheskii biulleten, 11, 45-51.

29. Khani, A., Baghbanan, A., Norouzi, S. Hashemolhosseini, H (2014). Effects of fracture geometry and Wittke W. Rock Mechanics Based on an Anisotropic Jointed Rock Model (AJRM). Verlag: Wilhelm Ernst \& Sohn, 875.

30. Shabanimashcool, M., Li, C. C. (2015). Analytical approaches for studying the stability of laminated roof strata. International Journal of Rock Mechanics and Mining Sciences, 79, 99-108. doi: http://doi.org/10.1016/j.ijrmms.2015.06.007

31. Wang, D. S., Chang, J. P., Yin, Z. M., Lu, Y. G. (2014). Deformation and failure characteristics of high and steep slope and the impact of underground mining. Transit Development in Rock Mechanics-Recognition, Thinking and Innovation, 451-457.

32. Iofis, M. A., Fedorov, E. V., Esina, E. N., Miletenko, N. A (2017). Advancement of geomechanics toward mineral wealth preservation. Gornyi Zhurnal, 11, 18-21. doi: http://doi.org/ 10.17580/gzh.2017.11.03

33. Khasheva, Z. M., Golik, V. I. (2015). The ways of recovery in economy of the depressed mining enterprises of the Russian Caucasus. International Business Management, 9 (6), 1210-1216.

34. Golik, V., Komashchenko, V., Morkun, V., Burdzieva, O. (2015) Metal deposits combined development experience. Metallurgical and Mining Industry, 7 (6), 591-594.

35. Karaman, K., Cihangir, F., Kesimal, A. (2015). A comparative assessment of rock mass deformation modulus. International Journal of Mining Science and Technology, 25 (5), 735-740. doi: http://doi.org/10.1016/j.ijmst.2015.07.006

36. Rudmin, M. A., Mazurov, A. K., Reva, I. V., Stebletsov, M. D. (2018). Prospects of integrated development of bakchar iron deposit (Western Siberia, Russia). Bulletin of the Tomsk Polytechnic University. Geo Assets Engineering, 329 (10), 85-94.

37. Мухаметшин, В. В., Андреев, В. Е. (2018). Increasing the efficiency of assessing the performance of techniques aimed at expanding the use of resource potential of oilfields with hardztozrecover reserves. Bulletin of the Tomsk Polytechnic University. Geo Assets Engineering, 329 (8), 30-36.

38. Kaplunov, D. R., Radchenko, D. N. (2017). Design philosophy and choice of technologies for sustainable development of underground mines. Gornyi Zhurnal, 11, 52-59. doi: http:// doi.org/10.17580/gzh.2017.11.10

39. Lyashenko, V. I., Khomenko, O. E. (2019). Enhancement of confined blasting of ore. Mining Informational and Analytical Bulletin, 11, 59-72. doi: http://doi.org/10.25018/0236-14932019-11-0-59-72

40. Lyashenko, V., Topolnij, F., Dyatchin, V. (2019). Development of technologies and technical means for storage of waste processing of ore raw materials in the tailings dams. Technology Audit and Production Reserves, 5 (3 (49)), 33-40. doi: http:// doi.org/10.15587/2312-8372.2019.184940

Lyashenko Vasil, PhD, Senior Researcher, Head of Research Department, State Enterprise «Ukrainian Research and Design Institute of Industrial Technology», Zhovti Vody, Dnepropetrovsk region, Ukraine, e-mail: vilyashenko2017@gmail.com, ORCID: http://orcid.org/ 0000-0001-8361-4179

Khomenko Oleh, Doctor of Technical Sciences, Professor, Department of Mining Engineering and Education, Dnipro University of Technology, Ukraine, e-mail: rudana.in.ua@gmail.com, ORCID: http:// orcid.org/0000-0001-7498-8494

Golik Vladimir, Doctor of Technical Sciences, Professor, Geophysical Institute, Federal State Budgetary Institution of Science of the Federal Science Center «Vladikavkaz Scientific Center of the Russian Academy of Sciences», Russian Federation, e-mail: vi.golik@mail.ru, ORCID: http://orcid.org/0000-0002-1181-8452

Topolnij Fedor, Doctor of Biological Sciences, Professor, Department of General Agriculture, State Higher Educational Institution «Central Ukrainian National Technical University», Kropyonytskyi, Ukraine, e-mail: topolniy@gmail.com, ORCID: http://orcid.org/0000-00023363-4646

Helevera Olha, PhD, Associate Professor, Department of Geography and Geoecology, State Higher Educational Institution «Volodymyr Vynnychenko Central Ukrainian State, Pedagogical University», Kropyvnytskyi, Ukraine, e-mail: olga.gelevera@gmail.com, ORCID: http:// orcid.org/0000-0002-1582-9714 